\title{
PROXIMATE COMPOSITION OF FRESHWATER RAINBOW TROUT (Oncorhynchus mykiss) IN RELATION TO BODY SIZE AND CONDITION FACTOR FROM PAKISTAN
}

\author{
Muhammad Naeem ${ }^{1, *}$, Abdus Salam ${ }^{1}$ and Amina Zuberi ${ }^{2}$ \\ ${ }^{1}$ Institute of Pure and Applied Biology, Bahauddin Zakariya University, Multan 60800, Pakistan; ${ }^{2}$ Fisheries and \\ Aquaculture Lab, Department of Animal Sciences, Faculty of Biological Sciences, Quaid-i-Azam University, \\ Islamabad, Pakistan. \\ *Corresponding author's e-mail: dr_naeembzu@yahoo.com
}

\begin{abstract}
Eighty four farmed Rainbow trout, Oncorhynchus mykiss ranging from 4.8-38.5cm total length and 1.11-725.00g body weight were collected for analyses of its body composition from Trout Hatchery, Masote near Kali Matti, Murree and Madian, Swat. The condition factor value of $O$. mykiss ranged from 0.831 to 1.607 . The mean percentage of water was found $77.82 \%$, for ash $12.77 \%$, for fat $22.79 \%$ and for protein content $64.42 \%$ in whole dry body weight of $O$. mykiss. Results showed that there was a strong correlation $(\mathrm{P}<0.001)$ in each of these body constituents (water, fat, protein and ash) with body size, weight and condition factor of the fish. Thus, with increasing body size, fat and protein contents increased in greater proportion, while ash and water percentage decreased. An inverse correlation was found in water and ash percentages, whereas percentage fat and protein showed positive correlation with condition factor.
\end{abstract}

Keywords: Oncorhynchus mykiss, body composition, protein, lipid, body size, allometry, condition factor, predictive equations.

\section{INTRODUCTION}

Rainbow trout, Oncorhynchus mykiss can be classified as the premier salmonid species. It is one of the most famous fish species in nature. At the same time, is also recognized and accepted as farmed fish species in many countries, because of its exceptional nutritive quality, rapid growth (Tekeliog, 2000) and exceptionally tolerant to environmental conditions (Simonovic, 2001). Worldwide production of rainbow trout was 537,000 tons in 2005 (FAO, 2007). Europe was the largest producer with 273,000, while Asia produces 97,000 tons (Vandeputte et al., 2008). O. mykiss is endemic to the Western region of North America. In 1973, Pakistan imported this species from Japan and introduced in its water bodies. Compared to other sources of protein, fish is an excellent source of proteins and essential nutrients for human diet (Arts et al., 2001; Fawole et al., 2007). In the developing countries, fish is considered as one of the best sources of protein (Louka et al., 2004). The nutritional value of the whole body is often used as an index of fish quality (Reinitz, 1983). The nutritional value of fish meat comprises the contents of moisture, dry matter, protein, lipids, vitamins and minerals, plus the caloric value of the fish (Evangelos et al., 1989; Steffens, 2006), while body composition and flesh quality are also essential characteristics of farmed fish species for human consumption. Body composition and flesh quality influence the consumer acceptance and human consumption (Kause $e t$ $a l .$, 2002). The measurement of some proximate profiles such as protein, lipids and moisture contents is often necessary to ensure that they meet the requirements of food regulations and commercial specifications (Waterman, 2000). Moreover, information concerning the chemical composition of freshwater fishes in general is valuable to nutritionists concerned with readily available sources of low-fat, highprotein foods such as most freshwater fishes (Mozaffarian et al., 2003; Foran et al., 2005), and to the food scientist who is interested in developing them into high-protein foods, while ensuring the finest quality flavor, color, odor, texture, and safety obtainable with maximum nutritive value (Mohamed $e t$ al., 2010). Body composition is also influenced by a great number of factors (Love, 1957; Weatherley and Gill, 1983a,b). It is observed that changes in the fish body composition are according to the size (Naeem and Ishtiaq, 2011), condition factor (Naeem and Salam, 2010; Naeem et al., 2011), and sex (Yousaf et al., 2011). Touhata et al. (1998) have shown that water temperature also affects the body composition of fish. While Suseno et al. (2010) have reported high protein and low fat content in fish due to increasing depth.

Condition factor has been used as an index of growth and feeding intensity (Fagade, 1979). A change of weight at a particular length, or a change of length, without corresponding change of weight with alters ' $\mathrm{K}$ ' (Weatherly and Gill, 1987). Therefore, the ' $\mathrm{K}$ ' value for a given fish 
measure the deviation from some hypothetical ideal fish of that fish growing isometrcially (Salam and Janjua, 1992).

Although a wealth of knowledge is available on the proximate composition of different fish species, however, to the best of our information, there is no published work in either national or international literature on the proximate composition of $O$. mykiss from Pakistan. So the present work was carried out to examine proximate composition of farmed rainbow trout, Oncorhynchus mykiss, and to verify its relationship with some biological variables like size and condition factor. Moreover, predictive equations were used to illustrate these relationships in farmed Rainbow trout, O. mykiss.

\section{MATERIALS AND METHODS}

Eighty four farmed Rainbow trout, Oncorhynchus mykiss, of different body sizes ranging from $4.8-38.5 \mathrm{~cm}$ total length and 1.11-725.00g body weight, were obtained from Trout Hatchery, Masote near Kali Matti, Murree and Madian, Swat using a cast net and transported alive to the Fisheries laboratory, Fish Seed Hatchery, Islamabad, Pakistan in plastic containers. These were anaesthetized with MS-222, individually weighed to the nearest $0.01 \mathrm{~g}$ on an electronic balance (OHAUS TS 400S) and their length measured to the nearest $0.1 \mathrm{~cm}$. Proximate composition of fish samples was analyzed. To determine water content, each whole fish sample was oven dried $\left(50-60^{\circ} \mathrm{C}\right)$ to a constant weight. Dry carcasses, of each fish sample, were powdered and subsamples taken for further analyses. Sub sample (500-1000mg) of each fish was ashed in duplicate using a muffle furnace (Bamford) for $24 \mathrm{~h}$ at $450-500^{\circ} \mathrm{C}$ to determine ash contents. The total lipid contents of dry tissue were determined by extraction in a $1: 2$ mixture of chloroform and methanol (Bligh and Dyer, 1959). Protein content was estimated by subtracting the mass of other main constituents, water, ash and fat, (Caulton and Bursell, 1977; Dawson and Grimm, 1980; Weatherley and Gill, 1987; Salam and Davies, 1994). Carbohydrates usually present in negligible amounts, thus do not form a major component of fish (Elliott, 1976; Caulton and Bursell, 1977; Weatherley and Gill, 1987; Salam and Davies, 1994).

Statistical analysis: In statistical analysis, regression analysis, correlation coefficients, standard error of the estimates, student's $t$-test, and plotting of data were carried out using EXCEL program following Zar (1996). The values of the compiled growth exponent were used for the calculation of condition factor, $\mathrm{K}$, by using the formula $K=$ $100 \times W / L^{3}$ following the method of Weatherly and Gill (1987) and Wootton (1990). The inter-relationships of body weight, total length and condition factor were carried out using a multiple regression model having the general form:

$$
\mathrm{Y}=\mathrm{a}+\mathrm{b}_{1} \mathrm{~W}+\mathrm{b}_{2} \mathrm{X}
$$

Where $\mathrm{a}, \mathrm{b}_{1}, \mathrm{~b}_{2}$ are constants, $\mathrm{W}$ is wet body weight and $\mathrm{X}$ is either total length (TL) or condition factor $(\mathrm{K})$ and $\mathrm{Y}$ is percent water, fat, protein or ash in wet body weight.

\section{RESULTS}

The regression parameters of various body constituents (percent water, ash, fat and protein contents) with size (weight and length) are given in Table 1. Student's $t$-test shows that the slopes $(b)$ of the regression lines are statistically different from $b=0$ in all cases. Each of body constituent was highly correlated $(\mathrm{P}<0.001)$ with fish size and weight. Increasing trend was found in fat and protein contents (as percentage) with increasing fish size, whereas water and ash contents (as percentage) decreased (Table 1; Fig. 1a-d). Strong correlation $(\mathrm{P}<0.001 ; \mathrm{r}>0.958)$ was found in each of these parameters of body composition (water, fat, protein and ash) with wet body weight (W) or total length (TL) (Table 2). Values of condition factor $(\mathrm{K})$ ranged from 0.831 to 1.607 . Water and ash percentages were observed inversely related to condition factor, whereas fat and protein percentages increased with increasing condition factor value. All these regressions were found statistically significant at $\mathrm{P}<0.001$ and $\mathrm{P}<0.01$ (Table 3). Multiple regression equation of each percent body constituent with body weight $(\mathrm{W})$, condition factor $(\mathrm{K})$ and

Table 1. Regression analysis and statistical parameters of \% body constituents (wet weight) with body weight (W; g) and total length (TL; cm).

\begin{tabular}{lccccc}
\hline Relationships & r & a & b & S. E. (b) & t value when b=0 \\
\hline W (x); \% Water (y) & $-0.734 * * *$ & 80.3405 & -0.0146 & 0.0014 & $10.4285^{* * *}$ \\
W (x); \% Fat (y) & $0.704^{* * *}$ & 3.9141 & 0.0077 & 0.0008 & $9.6250^{* * * *}$ \\
W (x); \% Protein (y) & $0.746^{* * *}$ & 16.8054 & 0.0154 & 0.0015 & $10.2666^{* * * *}$ \\
W (x); \% Ash (y) & $-0.397 * * *$ & 2.8540 & -0.0007 & 0.0001 & $7.0000^{* * *}$ \\
TL (x); \% Water (y) & $-0.775^{* * *}$ & 84.316 & -0.318 & 0.028 & $11.1719^{* * *}$ \\
TL (x); \% Fat (y) & $0.702^{* * *}$ & 2.003 & 0.159 & 0.017 & $8.9325^{* * *}$ \\
TL (x); \% Protein (y) & $0.776^{* * *}$ & 10.654 & 0.174 & 0.015 & $11.1538^{* * *}$ \\
TL (x); \% Ash (y) & $-0.381^{* * *}$ & 3.026 & -0.014 & 0.003 & $3.7692^{* * *}$ \\
\hline
\end{tabular}

$\mathrm{r}=$ Correlation Coefficient $; \mathrm{a}=$ Intercept $\mathrm{b}=$ slope $; \mathrm{S} . \mathrm{E}=$ Standard Error; $* * *: \mathrm{P}<0.001$ 
Table 2. Regression analysis and statistical parameters of body constituents with body weight (W; g) and total length (TL; cm).

\begin{tabular}{|c|c|c|c|c|c|}
\hline Relationships & $\mathbf{r}$ & $\mathbf{a}$ & b & S. E. (b) & t value when $b=1$ \\
\hline $\mathrm{W}(\mathrm{x})$; Water content $(\mathrm{y})$ & $0.998 * * *$ & 2.128 & 0.732 & 0.003 & \\
\hline Log W (x); Log water content (y) & $0.999 * * *$ & -0.068 & 0.977 & 0.021 & $1.0502^{\mathrm{ns}}$ \\
\hline $\mathrm{W}(\mathrm{x})$; Fat content $(\mathrm{y})$ & $0.958 * * *$ & -1.211 & 0.076 & 0.002 & \\
\hline $\log \mathrm{W}(\mathrm{x}) ; \log$ fat content $(\mathrm{y})$ & $0.985 * * *$ & -1.613 & 1.163 & 0.022 & $7.4318 * * *$ \\
\hline $\mathrm{W}(\mathrm{x})$; Protein content $(\mathrm{y})$ & $0.992 * * *$ & -1.061 & 0.165 & 0.002 & \\
\hline Log W (x); Log protein content (y) & $0.998 * * *$ & -0.981 & 1.071 & 0.006 & $10.6110 * * *$ \\
\hline $\mathrm{W}(\mathrm{x})$; Ash content $(\mathrm{y})$ & $0.993 * * *$ & 0.144 & 0.024 & 0.000 & \\
\hline Log W (x); Log ash content (y) & $0.996 * * *$ & -1.525 & 0.975 & 0.008 & $2.7701 * *$ \\
\hline $\log \mathrm{TL}(\mathrm{x}) ; \log$ water content $(\mathrm{y})$ & $0.997 * * *$ & -2.122 & 3.045 & 0.025 & $1.771^{\mathrm{n} \mathrm{s}}$ \\
\hline Log TL (x); Log ash content (y) & $0.995 * * *$ & -3.581 & 3.044 & 0.033 & $1.325^{\mathrm{n} \mathrm{s}}$ \\
\hline Log TL (x); Log fat content (y) & $0.979 * * *$ & -4.042 & 3.611 & 0.082 & $7.379 * * *$ \\
\hline Log TL (x); Log protein content (y) & $0.995 * * *$ & -3.233 & 3.338 & 0.034 & $9.950 * * *$ \\
\hline
\end{tabular}

$* * * \mathrm{P}<0.001 ; * * \mathrm{P}<0.01$

Table 3. Regression analysis and statistical parameters of percent body constituents (wet weight) with condition factor $(K)$ and percent water content.

\begin{tabular}{lccccc}
\hline Relationships & r & a & b & S. E. (b) & t value when b=0 \\
\hline K (x); \% Water (y) & $-0.459 * * *$ & 90.070 & -10.976 & 2.355 & $4.659 * * *$ \\
K (x);\% Fat (y) & $0.528 * * *$ & -2.555 & 6.992 & 1.241 & $5.631 * * *$ \\
K (x);\% Protein (y) & $0.356 * * *$ & 8.993 & 4.669 & 1.352 & $3.451 * * *$ \\
K (x); \% Ash (y) & $-0.304 * *$ & 3.490 & -0.685 & 0.236 & $2.897 * *$ \\
\% Water (x); \%Fat (y) & $-0.937 * * *$ & 45.5201 & -0.5174 & 0.021 & $24.405 * * *$ \\
\% Water (x); \%Protein (y) & $-0.937 * * *$ & 54.0846 & -0.5124 & 0.021 & $24.517 * * *$ \\
\%Water (x); \%Ash (y) & $0.319 * * *$ & 0.3951 & 0.0299 & 0.010 & $3.051 * * *$ \\
\hline
\end{tabular}

$* * * \mathrm{P}<0.001 ; * * \mathrm{P}<0.01$

Table 4. Multiple regression analysis and statistical parameters of percent body constituents with body weight (W, g) and condition factor (K) and total length (TL, cm).

\begin{tabular}{lcrrrr}
\hline Relationship & r & \multicolumn{1}{c}{$\mathbf{a}$} & \multicolumn{1}{c}{$\mathbf{b}_{1} \pm$ S.E } & $\mathbf{b}_{2} \pm \mathbf{S . E}$ & $\mathbf{r}^{\mathbf{2}}$ \\
\hline \% Water $=\mathrm{a}-\mathrm{b}_{1} \mathrm{~W}-\mathrm{b}_{2} \mathrm{~K}$ & $0.738^{* * *}$ & 82.56 & $-0.0137 \pm 0.0017$ & $-2.1411 \pm 2.1297$ & 0.5452 \\
\% Fat $=\mathrm{a}+\mathrm{b}_{1} \mathrm{~W}+\mathrm{b}_{2} \mathrm{~K}$ & $0.726^{* * *}$ & 1.01 & $0.0065 \pm 0.0009$ & $2.7918 \pm 1.1974$ & 0.5280 \\
\% Protein $=\mathrm{a}+\mathrm{b}_{1} \mathrm{~W}-\mathrm{b}_{2} \mathrm{~K}$ & $0.491^{* * *}$ & 13.26 & $0.0078 \pm 0.0010$ & $-0.3618 \pm 1.2309$ & 0.4914 \\
\% Ash $=\mathrm{a}-\mathrm{b}_{1} \mathrm{~W}-\mathrm{b}_{2} \mathrm{~K}$ & $0.412^{* * *}$ & 3.15 & $-0.0006 \pm 0.0002$ & $-0.2889 \pm 0.2697$ & 0.1697 \\
\% Water $=\mathrm{a}-\mathrm{b}_{1} \mathrm{~W}+\mathrm{b}_{2} \mathrm{TL}$ & $0.606^{* * *}$ & 80.95 & $-0.0049 \pm 1.0041$ & $0.6390 \pm 0.0515$ & 0.3683 \\
\% Fat $=\mathrm{a}+\mathrm{b}_{1} \mathrm{~W}-\mathrm{b}_{2} \mathrm{TL}$ & 3.02 & $0.0034 \pm 0.0008$ & $-0.0813 \pm 0.0331$ \\
\% Protein $=\mathrm{a}+\mathrm{b}_{1} \mathrm{~W}-\mathrm{b}_{2} \mathrm{TL}$ & $0.516^{* * *}$ & 0.2664 \\
\% Ash $=\mathrm{a}-\mathrm{b}_{1} \mathrm{~W}+\mathrm{b}_{2} \mathrm{TL}$ & $0.517 * * *$ & 12.16 & $0.0018 \pm 0.0008$ & $-0.0075 \pm 0.0315$ & 0.2675 \\
\hline
\end{tabular}

$* * * \mathrm{P}<0.001$

total length (TL, cm) were found highly significant at $\mathrm{P}<0.001$ (Table 4).

\section{DISCUSSION}

Although body composition is a good indicator of the physiological condition of a fish (Cui and Wootton, 1988), however, the information on the body composition of whole fish are scarce in Pakistan, and only a limited number of studies have carried out (e.g. Salam et al., 1991; Naeem et al., 2010, 2011; Naeem and Salam, 2010; Naeem and Ishtiaq,
2011; Yousaf et al., 2011). Percentage values of different body constituents found in this study are compared to the work of Staples and Nomura (1976) who have reported the body composition of Salmo gairdneri (Table 5). No studies on body composition of $O$. mykiss with relation to body size and condition factor were previously available in the scientific literature from Pakistan. The percentage of body constituents in this study is in general agreement with other workers (Staples and Nomura, 1976; Cui and Wootton, 1988; Salam and Davies, 1994; Salam et al., 2001; Naeem and Salam, 2010; Naeem and Ishtiaq,

2011) 
(a)

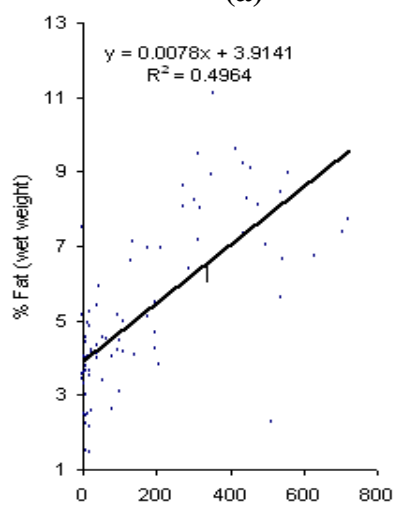

(b)

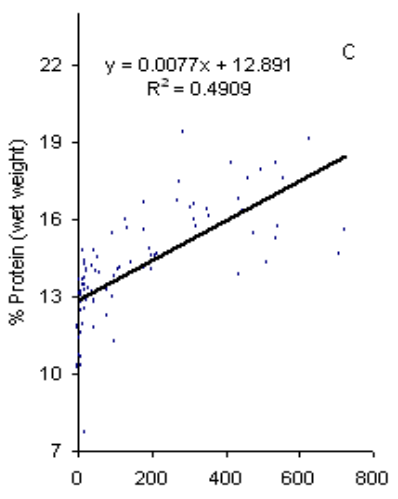

(c)

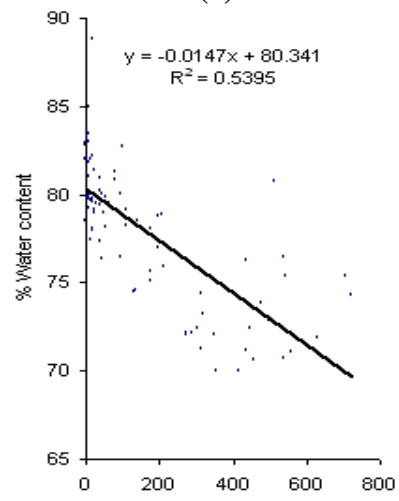

(d)

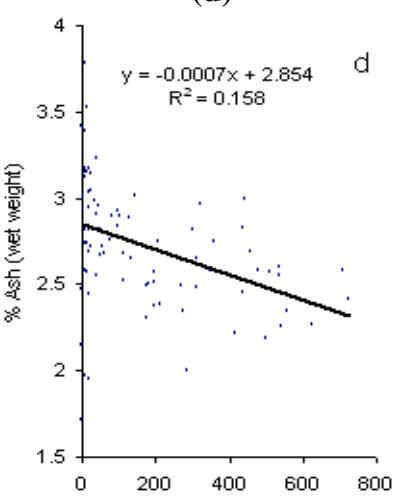

Figure 1. The relationship between wet body weight and (a) water contents, (b) fat contents, (c) protein contents and (d) ash content, in Oncorhynchus mykiss.

Table 5. Comparison of mean values ( \pm S.D) and ranges of various body constituents (dry body weight) in Oncorhynchus mykiss.

\begin{tabular}{lcccccc}
\hline Source & Size(g) & \% Water & $\begin{array}{c}\text { \% Fat (dry } \\
\text { wt.) }\end{array}$ & $\begin{array}{c}\text { \% Protein } \\
\text { (dry wt.) }\end{array}$ & $\begin{array}{c}\text { \% Ash (dry } \\
\text { wt.) }\end{array}$ & Tissue \\
\hline $\begin{array}{l}\text { Staples and Nomura (1976) } \\
\text { Present study }\end{array}$ & $3-1982$ & 73.26 & 23.88 & 62.54 & -- & Whole fish \\
\hline
\end{tabular}

who found fat and protein percentage increases with an increase in size (body weight or total length), whereas water and ash content decrease. In the present study, Huxley (1932) and Weatherley and Gill (1987) approaches were used to develop allometric predictive equations. Results revealed an isometry in all body constituents, body weight and length. Therefore, an increase in all body constituents was observed with increases in body weight and length. However, protein and fat constituents were found increasing with greater proportion (positive allometry) with an increase in total length when compared with $b=1$ for body weight and $b=3$ for total length as an isometric slope. More or less similar findings also recorded by Naeem et al. (2011) for female specie Notopterus notopterus. Significant correlation between various body constituents and condition factor in $O$. mykiss indicated that the body composition can successfully be estimated by condition factor as described by Salam and Davies (1994), Pangle and Sutton (2005), Naeem and Salam (2010), Naeem et al. (2011) and Yousaf et al. (2011). The results presented in this work showed that if it is not viable to estimate proximate composition of $O$. mykiss directly, then water content will provide satisfactory estimates of fat and protein contents. If it is unfeasible to find out water content, the body composition can be estimated directly from size of the fish using predictive regression models developed in this work with a reasonable amount of accuracy.

Furthermore, this investigation provides practical and useful information on the proximate composition of $O$. mykiss.
Conclusion: The findings of our study confirm that rainbow trout has considerable nutritional value (high protein content) for human consumption. Therefore, is necessary to promote the benefits of trout in the diet, in order to increase its consumption and use in human nutrition in Pakistan.

Acknowledgements: We thank Director General Fisheries, Lahore, Punjab, for technical support and availability of the animals.

\section{REFERENCES}

Arts, M.T., R.G. Ackman and B.J. Holub. 2001. Essential fatty acids in aquatic ecosystems: a crucial link between diet and human health and evolution. Can. J. Fisheries Aquatic Sci. 58:122-137.

Bligh, E.G. and W.J. Dyer. 1959. A rapid method of total lipid extraction and purification. Can. J. Biocham. Physiol. 37:911-917.

Caulton, M.S. and E. Bursell. 1977. The relationship between changes in condition and body composition in young Tilapia rendalli. J. Fish Biol. 11:1443-150.

Cui, Y. and R.J. Wootton. 1988. Bioenergetics of growth of Cyprinid, Phoxinus phoxinus ( $L$.), the effect of ration and temperature on growth rate and efficiency. J. Fish Biol. 33:763-773.

Dawson, A.S. and A.S. Grimm. 1980. Quantitative seasonal changes in the protein, lipid and energy content of the 
carcass, ovaries and liver of the adult female plaice, Pleuronectes platessa L. J. Fish Biol. 16:493-504.

Elliott, J.M. 1976. Body composition of brown trout, Salmo trutta L. in relation to temperature and ration size. $J$. Comp. Physiol. 114:191-202.

Evangelos, S.L., G. Aggelousis and A. Alexakis. 1989. Metal and proximate composition of the edible portion of 11 freshwater fish species. J. Food Comp. Anal. 2:37-381.

Fagade, S.O. 1978. Age determination of Tilapia melanotheron (Ruppel) in the Lagos Lagoon Nigeria. Int. Symp. Ageing Fish in Bagenal, Teseh. 71-77.

Food and Agriculture Organization. 2007. Aquaculture production: quantities 1950-2005 FISHSTAT Plus. Available online with updates at: http://www.fao.org/fi/statist/FISOFT/FISHPLUS

Fawole, O.O., M.A. Ogundiran, T.A. Ayandiran and O.F. Olagunju. 2007. Mineral Composition in some selected fresh water fishes in Nigeria. J. Food Safety 9:52-55.

Foran, J.A., D.O. Carpenter, M.C. Hamilton, B.A. Knuth and S.J. Schwager. 2005. Risk- based consumption advice for farmed Atlantic and wild pacific salmon contaminated with dioxins and dioxin- like compounds. Environ. Health. Persp. 33:552-556.

Huxley, J.S. 1932. Problems of relative growth. Methuen, London.

Kause, A., O. Ritola, T. Paananen, E. Mäntysaari and U. Eskelinen. 2002. Coupling body weight and its composition: A quantitative genetic analysis in rainbow trout. Aquaculture 211:65-79.

Louka, N., F. Juhel, V. Fazilleau and P. Loonis. 2004. A novel colorimetry analysis used to compare different drying fish processes. Food Control 15:327-334.

Love, R.M. 1957. The biochemical composition of fish. p. 401-418. In: M.E. Brown (ed.), Physiology of Fishes. Academic Press Inc., New York.

Mohamed, H.A.E., R. Al-Maqbaly and H. M. Mansour. 2010. Proximate composition, amino acid and mineral contents of five commercial Nile fishes in Sudan. Afr. J. Food Sci. 4:650-654.

Mozaffarian, M.D., N.L. Rozenn, H.K. Lewis, L.B. Gregory, P.T. Russell and S.S. Davis. 2003. Cardiac benefits of fish consumption may depend on type of fish meal consumed. Circulation 107:1372-1382.

Naeem, M. and A. Salam. 2010. Proximate composition of fresh water bighead carp, Aristichthys nobilis, in relation to body size and condition factor from Islamabad, Pakistan. Afr. J. Biotechnol. 9:8687-8692.

Naeem, M., A. Salam, M. Khalid and M. Ashraf. 2010. Effect of body size and condition factor on whole body composition of immature population hatchery reared mahseer, Tor putitora from Pakistan, pp.286-289. In: Yang Dan (ed.), $2^{\text {nd }}$ International Conference on Chemical, Biological and Environmental Engineering (ICBEE 2010); 2-4 Nov. 2010, Cairo, Egypt.
Naeem, M., A. Rasul, A. Salam, S. Iqbal, A. Ishtiaq and M. Athar. 2011. Proximate analysis of female population of wild featherback fish (Notopterus notopterus) in relation to body size and condition factor. Afr. J. Biotechnol. 1019:3867-3871.

Naeem, M. and A. Ishtiaq. 2011. Proximate composition of Mystus bleekeri in relation to body size and condition factor from Nala Daik, Sialkot, Pakistan. Afr. J. Biotechnol. 10:10765-10763.

Pangle, K.L. and T.M. Sutton. 2005. Temporal changes in the relationship between condition indices and proximate composition of juvenile Coregonus artedi. J. Fish Biol. 66:1060-1072.

Reinitz, G. 1983. Relative effect of age, diet, and feeding rate on the body composition of young rainbow trout (Salmo gairdneri). Aquaculture 35:19-27.

Salam, A., M.N. Khan and M. Naeem. 1991. Effect of body size and condition factor on body composition of an exotic fish, Tilapia nilotica. Proc. Pak. Cong. Zool. 11:91-200.

Salam, A. and M. Y.Janjua, 1992. The relationship between changes in the body size, condition factor and body composition in young Rohu, Labeo rohita. J. Res. Sci. 4:7-13.

Salam, A. and P.M.C. Davies. 1994. Body composition of northern pike (Esox lucius L.) in relation to body size and condition factor. Fish. Res. 19:193-204.

Salam, A., M. Ali and M. Anas. 2001. Body composition of Oreochromis nilotica in relation to body size and condition factor. Pak. J. Res. Sci. 12:19-23.

Simonović, P., 2001. Ribe Srbije. NNK International, Zavod za zaštitu prirode Srbije, Biološki fakultet.

Staples, D.J. and M. Nomura. 1976. Influence of body size and food ration on the energy budget of rainbow trout, Salmo gairdneri. J. Fish Biol. 9:26-43.

Steffens, W. 2006. Freshwater fish- wholesome foodstuffs. Bulg. J. Agric. Sci. 12:320-328.

Suseno, S.H., A.Y. Tajul, W.A. Nadiah, Hamidah, Asti and S. Ali. 2010. Proximate, fatty acid and mineral composition of selected deep sea fish species from Southern Java Ocean and Western Sumatra Ocean, Indonesia. Int. Food Res. J. 17:905-914.

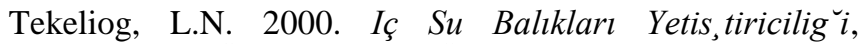
Çukurova Üniversitesi Su Ürünleri Fakültesi Ders Kitabı No-2, Adana, Turkey.

Touhata, K., H. Toyohara, M. Tanaka, Y. Tokuda, M. Sakaguchi and H. Tanaka. 1998. Seasonal change in muscle firmness and proximate composition of red seabream. Fish. Sci. 64:513-516.

Vandeputte, M., A. Storset, A. Kause and M. Henryon. 2008. Review on Breeding and Reproduction of European aquaculture species: Rainbow trout (Oncorhynchus mykiss). Aqua Breed. pp.1-17. 
Waterman, J.J. 2000. Composition and Quality of Fish. Torry Research Statation, Edinburgh.

Weatherley, A.H. and H.S. Gill. 1983a. Relative growth of tissue at different somatic growth rates in rainbow trout Salmo gairdneri Richardson. J. Fish Biol. 22:43-60

Weatherley, A.H. and H.S. Gill. 1983b. Protein, lipid, water and caloric contents of immature rainbow trout, Salmo gairdneri Richardson, growing at different rates. J. Fish. Biol. 23:653-673.
Weatherley, A.H. and H.S. Gill. 1987. The biology of fish growth. Academic Press; London.

Wootton, R.J. 1990. Ecology of Teleost Fishes. Chapman and Hall; London.

Yousaf, M., A. Salam and M. Naeem. 2011. Body composition of freshwater Wallago attu in relation to body size, condition factor and sex from southern Punjab, Pakistan. Afr. J. Biotechnol. 10:4265-4268.

Zar, J.H. 1996. Biostatistical Analysis. Prentice-Hall; New Jersey. 